\title{
Role of Emotional Intelligence in Leadership and Organizational success
}

\author{
Sivanjali M \\ Department of Medical Education and Research, Eastern University, Sri Lanka
}

\begin{abstract}
Emotional Intelligence (EI) plays a significant role in creating leadership skills and making an effective workplace. Positive work environment will enable everyone to understand each other, manage their own emotions in positive ways to relieve stress, communicate effectively, empathize with others, and help to manage relationships within the organization.
\end{abstract}

The objective was to explore the association of emotional intelligence in leadership and organizational success among the study participants.

Observational study was done among participants for a period of six months. The study was conducted among healthcare professionals, bank employees and self-employed workers in the city of Batticaloa, Sri Lanka $(n=9)$. Two physicians and one nurse were considered in Health care workers. Among bank employees, two of them were in the manager positions and one of them worked in customer service. In self-employed workers' different categories and stages of employees were considered. One of them was a lawyer, one private tutor and one retail businessman. Content analysis was done manually. Themes identified were career satisfaction and having work-life balance. In all categories of career, stage and nature of career had an influence on career satisfaction and work life balance. Career satisfaction was measured by achieving the targets and feeling peaceful at work place. When we considered career satisfaction $100 \%$ of self-employed workers had it and $70 \%$ of Health-care workers and Bank employees expressed it. When considering the work life balance $70 \%$ of the self-employed workers had work life balance and in other professions less than $50 \%$ of them had a good work life balance.

It was proved that employees with higher Emotional Intelligence had career satisfaction; good work life balance and they could lead the organization in a successful way.

Key words: Content analysis, Emotional Intelligence (EI), Leadership skills, Organizational success

\section{INTRODUCTION}

$\mathrm{E}$ motional intelligence (EI) has a significant role in creating good leadership skills and making the workplace an effective entity. Positive environment will enable everyone to understand each other, manage their own emotions in positive ways to relieve stress, communicate effectively, empathize with others, and help to manage relationships within the organization. These characteristics would lead to the success of an organization. Employees have different attitudes in the workplace depending on their career choice and satisfaction; it has a greater role in how they behave at work. When employees have a positive mood and engagement in their work, they will have better career satisfaction (Extremera et al., 2018). There is another study on healthcare shows that when employees have high EI, they will have higher engagement in work which is necessary to a Healthcare organization to function effectively (Pérez-Fuentes et al., 2018)

Nowadays we see that employees are more intensive on work-life balance and overall life satisfaction (Urquijo et al., 2019). They also look for the career which fulfils their financial need greatly and ultimately which gives them a complete satisfaction in life. Employees working hours and their personal life such as household work, marital status, and having dependent children have a major influence on having career satisfaction and work life balance. Most physicians have poor career satisfactions due to inadequate work life balance (Keeton et al., 2007). A female physician said that she was influenced by the family and teachers during her middle school to take this pathway. Even though she has values in the society because of her chosen profession, she feels miserable in life that she cannot give her full effort at home as well as to the workplace. She was married and had dependent children. She felt guilty that she could not spend much time with her kids. When women choose a career they often look for employment which has flexible working hours and is not much demanding like emergency care. They are often forced to the teaching profession since the working hours are less and also they have more holidays compared to other professions. When the responsibility is shared by the partner they become relaxed and willing to choose a career that they prefer to work. This may take a long way in some communities. Even in my study the responsibility was not shared equally due to social beliefs and culture of communities. Though the men were very much forthcoming in sharing the responsibility the cultural norms were not very supportive. In some families women stay at home due to more social responsibilities and when we think about the overall economy it is not considered gratifying for the growth of an individual as well as the country.

Another study found out that the career choices depend on the personality traits which have greater influence on career satisfaction and career success (Lounsbury et al., 2003). It is evident that most of them would prefer to choose a career depending on their personalities, but again there would be social pressures to choose a career beyond their personality traits. 
It was believed that EI has attributes such as selfmanagement, self-awareness, social awareness and relationship management. Recognizing everyone's own emotions is important which has an influence on their thought and behavior that they have to navigate these emotions in a healthy way. When people have social awareness, they have empathy. This makes them understand the emotions and needs of others, feel comfortable and recognize the power dynamics in an organization to work successfully. Team work and efficient communication eventually lead to resolving conflicts at the workplace.

It is in these contexts this study was performed among certain selected staff working in different sectors. Nowadays all employees are greatly looking for careers where they could have a work-life balance. Factors that have an Influence on work life balance are demands of a person/society, work culture, work orientation, personality, gender, stage of life and the stage of career (Guest, 2002).

Dual-earner families are struggling to achieve the balance; they often say that their job prevents them from spending more time with family (Lockwood, 2003). When we think about the social dynamics the family matters more than any other aspects of life. For the human being to function effectively there should be a balance between the social aspects and career where these aspects have to be considered. When the employee is recruited for the employment the Human Resource has to consider the factors which have influence on the person's career satisfaction. It would be a good practice to have an open communication at the beginning with the employees to get more benefits from them. It can benefit both sides to talk about the social aspects as well since it has a major influence on a person's career satisfaction. The previous studies were mostly from the western society, I wanted to do a study in our South Asian communities where the social influences are more and becoming very challenging to employees who would like to perform better at the workplace.

\section{OBJECTIVE}

The objective was to know the influence of social aspects among different categories of workers to have emotional intelligence which leads to leadership and organizational success.

\section{METHOD}

Participants were selected by purposive sampling, considering varied nature of career, stage of career, gender, marital status and dependent kids.

Observational study was done among participants for a period of six months. Data was collected by observing the participants in general situations and engaging them in a general unstructured conversation. Unstructured individual phone interviews were also done to talk about their general views and experiences about their career, career satisfaction and how they are managing work and life. First they were allowed to talk openly about their career that they are in now.

The selected employees worked as healthcare professionals, bank employees and self-employed workers in the city of Batticaloa, Sri Lanka $(n=9)$. Nature of career, stage of career, gender, marital status and dependent kids were considered to analyse data and to come to a conclusion. Two physicians and one nurse were considered as health care workers. Among them one male physician, one female physician and a female nurse. Among bank employees, two of them were in the manager positions and one of them worked in customer service. When we considered the gender one manager was a male other one was a female manager and the one worker in the customer service was a female employee. In selfemployed workers' different categories and stages of employees were considered. One of them was a lawyer and she was a female, one private tutor and he was a male and a male retail businessman.

Content analysis was done manually. Overall marital status and gender were considered along with other factors which affect Emotional intelligence among different categories of work. Themes identified were career satisfaction, having work-life balance which ultimately leads to organizational success.

\section{RESULT}

In all categories of career, stage and nature of career had an influence on career satisfaction and work life balance. My identified themes were career satisfaction and work-life balance which leads to organizational success. Career satisfaction was measured by achieving the targets and feeling peaceful at work place.

The factors which were looked at work-life balance are how relaxed they felt managing family and career, time pressures and work load at both places.

Table I

\begin{tabular}{|c|c|c|c|c|}
\hline & & $\begin{array}{l}\text { Number of } \\
\text { Employees }\end{array}$ & $\begin{array}{c}\text { Career } \\
\text { satisfaction } \\
(\%)\end{array}$ & $\begin{array}{l}\text { Work- } \\
\text { life } \\
\text { balance } \\
(\%)\end{array}$ \\
\hline \multirow{2}{*}{$\begin{array}{l}\text { Healthcare } \\
\text { Professionals }\end{array}$} & Physician & 2 & \multirow{2}{*}{67} & \multirow{2}{*}{33} \\
\hline & Nurse & 1 & & \\
\hline \multirow{2}{*}{$\begin{array}{c}\text { Bank } \\
\text { Employees }\end{array}$} & Manager & 2 & \multirow[b]{2}{*}{67} & \multirow[b]{2}{*}{33} \\
\hline & $\begin{array}{l}\text { Customer } \\
\text { service } \\
\text { worker }\end{array}$ & 1 & & \\
\hline \multirow{3}{*}{$\begin{array}{c}\text { Self- } \\
\text { employed } \\
\text { workers }\end{array}$} & Lawyer & 1 & \multirow{3}{*}{100} & \multirow{3}{*}{67} \\
\hline & Private tutor & 1 & & \\
\hline & $\begin{array}{c}\text { Retail } \\
\text { Businessman }\end{array}$ & 1 & & \\
\hline
\end{tabular}


When we considered the satisfaction at work, only two health care professionals felt satisfied at work and only one person had a good work life balance. Further he added that since his wife was taking care of his family, he could experience the balance. Another female physician said that if there is not much pressure she would be more efficient and could not do it at this moment since she has other responsibilities. A female nurse also disclosed the same matter. When I inquired further they said that their spouses were working and it was very hard to have a challenging situation when they have to attend the emergency care very often. The families who had dependent children faced more challenges and women felt more dissatisfied due to more demanding social responsibilities. Self- employed workers were having more flexible working hours since they could choose to work the time which suits their personal needs and they had well managed work life balance. Among them all of them were satisfied at their job and the employers who had higher education had higher Emotional Intelligence and felt satisfied and were able to run the organization in a successful manner with a satisfied career and work-life balance. When I spoke to the retail businessman he said that even though he could be flexible, in order to provide the customer service in comparison with the other businessmen he has to stick to a routine time to be more economical. But again he feels stressful at times as a single person earning a family with more economic responsibilities. When I interviewed the bank employees the managers were satisfied at work and one of them had a good work-life balance. One manager described that even though he feels to be having flexibility, he feels as if he is sitting on a thorny chair with more responsibilities. The employee who worked in customer service also felt stressed out that she had to manage people with different personalities every day and more responsibility with handling money. When we considered the overall themes of career satisfaction and work life balance the self-employed workers admitted to have them compared to other professions. A lawyer conversed to have her own business rather than joining a particular firm is to have a balanced work and life. She convinced me that there is no point in working for long hours without having a family life which is acceptable. Private tutor was in his early stages of career, but again he was clear on having employment on his own. He also added with this self-employment he could handle another self-employment since he gets to decide on matters. He could do that depending on his personal and family preferences.
Figure I

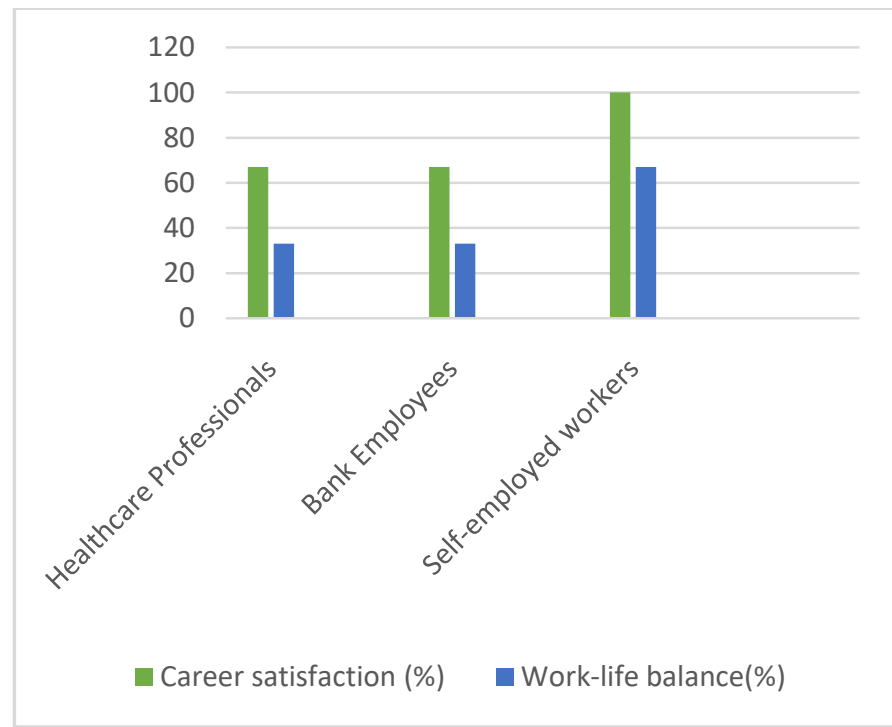

As shown in table I and figure 1, Career satisfaction was $100 \%$ in self-employed workers and nearly $70 \%$ of Healthcare workers and Bank employees expressed it. When considering the work life balance nearly $70 \%$ of the selfemployed workers had work life balance and in other professions less than $50 \%$ of them had a good work life balance.

\section{DISCUSSION AND CONCLUSION}

It was proved that employees with higher Emotional Intelligence had career satisfaction, good work life balance and they could lead the organization in a successful way! EI can be learned and developed at any age or circumstances. Studies have shown that with increasing age and work experience, people learn to adapt to the different environments easily and their problem solving abilities increase as well (Vahidi et al., 2016). EI has shown dynamic relations with many psychological significance such as health and well-being of individuals which can lead to greater job performance and work attitudes (Mérida-López et al., 2017).

A study which was done among physicians in Greece showed that job satisfaction was high among physicians who had high EI (Psilopanagioti et al., 2012). In our study also, employees who reached higher stages by education or experience showed greater Emotional intelligence at work.

Emotional intelligence was influenced by nature and stage of career. People with high EI tend to contribute more towards the success of the organization. When employees have high EI they could navigate through the social variations at the workplace and motivate others to perform better. There was another study which supports our results that people have a firm mind, confidence and in managerial positions had greater job satisfaction (Lounsbury et al., 2003).

There was one more study which looked for positive leadership and psychological empowerment leading to career 
satisfaction. It was noted that when the employees are psychologically empowered they show greater job satisfactions and become more creative, more efficacious and task oriented which leads to the success of the organization. Employees who had greater meaning and skill for their job were self-determined and had greater satisfaction in their job (Brian Joo \& Lim, 2013).

There was a study which assessed the stress level of nurses, the results showed that the less experienced nurses had more stress and when there is lesser the stress, more the career satisfaction (Hoffman \& Scott, 2003). We could see that there is a higher level of growth worldwide because of the increase in the workforce of women, at the same time the family conflicts are on the rise since women have to have a dual role with domestic as well as official responsibilities. This change can be a successful one if both shared the family responsibilities rather than women alone (Crompton et al., 2005).It is evident that having flexible working hours decreases work-life conflict (McCarthy et al., 2017).

It was found out that working in altered schedules of time, has an impact on work-life balance leading to dissatisfaction of marriage and family (Tausig \& Fenwick, 2001). We could see this in Health-care professionals. Some workplaces offer family friendly encouragement to employees without compromising their work responsibilities. To have work/life balance employees need to have support at work, home and in the community as well. When there is imbalance it affects family and advancements at work place (White et al., 2003).

This study concludes that employees at a higher grade tend to show greater career satisfaction. It was evident that physicians had greater career satisfaction and among self- employed workers all of them had greater career satisfaction. Selfemployed workers regardless of the stage of their career showed greater work-life balance compared to other professions. From our study we think that it would be wise to talk about the employees' personal choices and responsibilities when they are hired for the employment. Our study also proves what was said by Beutell, the saying is having a satisfied career determines the success of life (BEUTELL, 1999).

\section{REFERENCE}

[1] Agnoli, S., Mancini, G., Andrei, F., \& Trombini, E. (2019). The relationship between trait Emotional Intelligence, cognition, and Emotional Awareness: An interpretative model. Frontiers in Psychology, 10(JULY). https://doi.org/10.3389/fpsyg.2019.01711

[2] Extremera, N., Mérida-López, S., Sánchez-álvarez, N., \& Quintana-Orts, C. (2018). How does emotional intelligence make one feel better at work? The mediational role of work engagement. International Journal of Environmental Research and Public Health, 15(9). https://doi.org/10.3390/ijerph15091909
[3] Jakobsen, M. D., Sundstrup, E., Brandt, M., Jay, K., Aagaard, P., \& Andersen, L. L. (2015). Physical exercise at the workplace prevents deterioration of work ability among healthcare workers: Cluster randomized controlled trial. BMC Public Health, 15(1), 19. https://doi.org/10.1186/s12889-015-2448-0

[4] Mérida-López, S., Extremera, N., \& Rey, L. (2017). Contributions of work-related stress and emotional intelligence to teacher engagement: Additive and interactive effects. International Journal of Environmental Research and Public Health, 14(10). https://doi.org/10.3390/ijerph14101156

[5] Pérez-Fuentes, M. del C., Molero Jurado, M. del M., Gázquez Linares, J. J., \& Oropesa Ruiz, N. F. (2018). The role of emotional intelligence in engagement in nurses. International Journal of Environmental Research and Public Health, 15(9). https://doi.org/10.3390/ijerph15091915

[6] Psilopanagioti, A., Anagnostopoulos, F., Mourtou, E., \& Niakas, D. (2012). Emotional intelligence, emotional labor, and job satisfaction among physicians in Greece. BMC Health Services Research, 12(1), 1. https://doi.org/10.1186/1472-6963-12-463

[7] Ranasinghe, P., Wathurapatha, W. S., Mathangasinghe, Y., \& Ponnamperuma, G. (2017). Emotional intelligence, perceived stress and academic performance of Sri Lankan medical undergraduates. BMC Medical Education, 17(1), 17. https://doi.org/10.1186/s12909-017-0884-5

[8] Segal, J. (2019). Improving Emotional Intelligence ( $E Q)$ When it comes to happiness and success in life, emotional intelligence matters just as much as intellectual ability. Learn how you can boost your EQ . 1-7. https://www.helpguide.org/articles/mentalhealth/emotional-intelligence-eq.htm

[9] Tsirigotis, K. (2016). Indirect Self-Destructiveness and Emotional Intelligence. Psychiatric Quarterly, 87(2), 253263. https://doi.org/10.1007/s11126-015-9387-x

[10] Urquijo, I., Extremera, N., \& Azanza, G. (2019). The contribution of emotional intelligence to career success: Beyond personality traits. International Journal of Environmental Research and Public Health, 16(23). https://doi.org/10.3390/ijerph16234809

[11] Vahidi, M., Namdar Areshtanab, H., \& Arshadi Bostanabad, M. (2016). The Relationship between Emotional Intelligence and Perception of Job Performance among Nurses in North West of Iran. Scientifica, 2016. https://doi.org/10.1155/2016/9547038

[12] Crompton, R., Lyonette, C., Crompton, R., \& Lyonette, C. (2005). Work-life 'balance 'in Europe. 10, 1-32.

[13] Guest, D. E. (2002). Perspectives on the study of work-life balance. Social Science Information, 41(2), 255279. https://doi.org/10.1177/0539018402041002005

[14] Lockwood, N. R. (2003). Work/Life Balance: Challenges and Solutions for Human Resource Management. SHRM Research, 110.

[15] McCarthy, A., Cleveland, J. N., Hunter, S., Darcy, C., Grady, G., Aleksić, D., Mihelič, K. K., Černe, M., Škerlavaj, M., HUI, C. S., YEE, C. S., YEN, L. S., CHIE, L. A., YI, L. C., Cegarra-Leiva, D., Eugenia Sánchez-Vidal, M., Cegarra-Navarro, J. G., Life, O. W., Smith, J., ... Encyclopedia. (2017). the Impact of Perceived Organizational. Personnel Review, 46(3), 97-108.

[16] Tausig, M., \& Fenwick, R. (2001). Unbinding time: Alternate work schedules and work-life balance. Journal of Family and Economic Issues, 22(2), 119. https://doi.org/10.1023/A:1016626028720

[17] White, M., Hill, S., McGovern, P., Mills, C., \& Smeaton, D. (2003). "High-performance" management practices, working hours and work-life balance. British Journal of Industrial Relations, 41(2), 8543.00268 